\title{
Organizational Climate and Transfer of Training in a Public Corporation in Qatar
}

\author{
By: Dr. Thamer Mohammed Maharmeh \\ Ph.D. in Business Administration, Institute of Administrative Development- State of Qatar \\ Email: tmharma@adlsa.gov.qa
}

\begin{abstract}
The current research investigates the association between organizational climate and training transfer in case of a Qatari public corporation. It seeks to enhance training transfer through improving the organizational climate. To meet the objectives of the research, survey was developed and distributed to all employees who work for the selected corporation. (152) surveys were returned and analyzed by using SPSS. Results of data analysis revealed that there are positive attitudes towards transfer of training. In other words, employees believe that training influences their performance and behavior. Besides, employees transfer what they learned in training into their workplace. It was also found that employees perceive the overall organizational climate and the dimensions of organizational climate positively. This gives indicator of positive attitudes and perceptions of organizational climate. Regarding the relationship between the dimensions of organizational climate and transfer of training, results of data analysis revealed that there are strong and positive relationships between employee perceptions of eight dimensions of organizational climate and transfer of training into the workplace. It was found that there were positive and strong relationships between employee perceptions of support, responsibility, structure, conflict, identity, warmth, support, and risk on one hand, and their perceptions of training transfer on the other hand. Still, the relationship employee perceptions of rewards and their perceptions of training transfer was weak and not significant.
\end{abstract}

Keywords: Training, Transfer of training, Organizational climate, Public corporation. 


\author{
أثر المناخ التنظيمي على نقل أثر التدريب في مؤسسة عامة قطرية

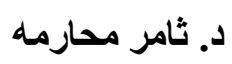 \\ دكتور اه إدارة أعمال، معهد الإدارة العامة - دولة قطر \\ tmharma@adlsa.gov.qa
}

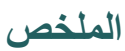

نظر الأهمية التدريب و أثره على الأداء الفردي و المؤسسي، فقد جاء هذا البحث لدر اسة أحد العو امل التي قد تؤثر في نقل أثر التدريب إلى مواقع العمل وهو المناخ التنظيمي السائد. هدف البحث إلى الكثف عن نأثثر تصور ات الموظفين للمناخ التنظيمي السائد في منظمتهم على نقل أثر التدريب للعمل في مؤسسة عامة بدولة قطر . تم تصميم استبانة وتوزيعها على موظفي المؤسسة

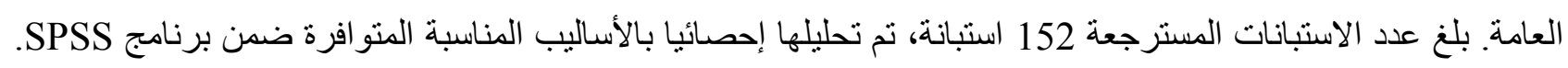
كثفت نتائج التحليل عن وجود علاقة إيجابية وقوية ودالة إحصائيا بين تصورات الموظفين للمناخ التنظيمي السائد من جهة، وقيام الموظفين بنقل أثر التدريب لمواقع العمل من جهة أخرى. ومن هنا، ولتحسين مستويات نقل أثر التدريب لمواقع العمل لا بد من بناء مناخ تنظيمي إيجابي يستند إلى الدعم والتشجيع و العلاقات الإيجابية.

الكلمات المفتاحية: التدريب. نقل أثر التدريب. المناخ التنظيمي. المؤسسة العامة. 


\section{Introduction}

\subsection{Background}

Many organizations all over the world allocate huge budgets for training and development. They consider this as an investment in human capital (Graham, 2015). It is expected that training positively influence employee and organizational performance. This is because training helps to refresh knowledge, enhance skills and competencies, prepare employees for future jobs, and enhance productivity. Besides, training is important for all employees as training helps to enable employees to cope with changes and empower them with skills to carry their duties effectively. For example, one report found that organizations that had invested the most in training had a stockholder return $86 \%$ higher than firms who had invested the least in training (Bhatia, 2014). As organizations make huge efforts to develop employees, and as they make huge investment in training and development, organizations expect to get returns from such investment. They expect that employee transfer what they gain from training into the workplace (Pukkeeree, 2017). For organizations, the real measure of the benefits of training is the transfer of training in the workplace. If employees transfer what they learned from training into the workplace, this gives indicator of the success of training and the association between training classes and the real world. Despite such expectations, it seems that the issue does not go in the right track all the time. In simple words, employees may nit transfer training into the workplace (Salas, 2018). Baldwin \& Ford (1997) noted only 10 percent of training outcomes are transferred back to the job. For organizations, this is a waste of time and efforts. Based on that, training transfer becomes a crucial issue in human resource development (HRD).

Over the past 30 years, there has been an explosion of research in HRD literature devoted to transfer of training - and much has been learned (Blume,2017). This is because low rate of transfer of training negatively influences investments in training and negatively influences the association between training and performance (Schiattone, 2017). This justifies why many scholars and researchers have been making efforts to understand factors that influence training transfer. Scholars and researchers have been efforts to ease transfer of training into the workplace through identifying personal and organizational factors associated with transfer of training (Foxon, 1993). Understanding such factors will help to ease and maximize transfer of training into workplace. 


\subsection{Research Problem}

Recognizing the importance of training and its effects on employee skills and organizational performance, public corporations in Qatar allocate budgets and make huge investment in training. Despite all efforts to provide all employees with training and to make training a continuous process, it is noted that no efforts have been made to explore the impact of training on performance. Besides, no one study has taken place to investigate the transfer of training into the workplace. The research problem relates to the need to maximize the contributions of training to individual and organizational performance. In other words, public corporations in Qatar need to make sure that their efforts and investments in training generate positive impacts on performance. This is crucial because thousands of employees participate in training courses annually.

The current study investigates a key factor that might influence transfer of training into the work place, which is organizational climate. This is because supportive climate play critical role in enhancing transfer of training into the workplace (Abujazar, 2014). The research explores specific research problem related to the evaluation of transfer of training in case of a public corporation in Qatar, and the association between organizational climate and transfer of training. Based on that, the research seeks to answer the following key research question: What is the relationship between employee perceptions of the organizational climate and transfer of training into the workplace? This research seeks to answer the following research questions:

1. How employees at the selected Qatari public corporation perceive organizational climate of their corporation?

2. How employees at the selected Qatari public corporation perceive transfer of training into the workplace?

3. What is the relationship between organizational climate and perceived training transfer?

\subsection{Research Objectives}

The overall aim of the current research is to enhance training transfer through improving the organizational climate. The main objective of the research is to investigate the association between organizational climate and training transfer in case of a public corporation in Qatar, 
To build better climate that enhances, and eases transfer of training into the workplace. The research specifically seeks to:

1. Explore how employees perceive the organizational climate at a Qatari public corporation.

2. Explore how employees perceive transfer of training into the workplace of the selected public corporation.

3. Investigate the impact of organizational climate on perceived training transfer.

4. Come up with recommendations to enhance training transfer through building better organizational climate.

\subsection{Importance of the Research}

The research explores how employees transfer training into the workplace and the association between employees' perceptions of organizational climate and their transfer of training. This issue is important for many reasons. On one hand, it helps to provide management of the selected public corporation with information about the training transfer. This issue is important because the management needs to make sure that efforts of developing and investing in training are associated with positive effects on performance. On the other hand, it is important to evaluate the efforts and investments in training. This is because poor evaluation exercises have been attributed to organizations' inability to determine the value added by training to the organizational performance hence the organizations report high investments in training with poor returns (Greg $\&$ Diane, 2016). Adding to that, there are many factors influences transfer of training. The research explores the association of training transfer with one factor that is organizational climate. This is mainly because organizational climate is crucial factor that may associate with all workrelated issues, including transfer of training. Despite that, very limited number of researchers investigated organizational climate association with transfer of training (Clark et al., 1993, Chiaburu \& Tekleab, 2015, Brinia, 2012, Burke \& Baldwin, 1999, Awortwi, 2013, Banerjee et al., 2017). By investigating the association between organizational climate and training transfer, the research will help to build better climate that enhances, and eases transfer of training at the selected public corporation. 


\subsection{Research Hypothesis}

The research seeks to test the following hypothesis:

$\mathrm{H} 1$ : There is significant relationship between organizational climate and transfer of training.

$\mathrm{H} 2$ : There is significant relationship between dimensions of organizational climate (support, responsibility, structure, conflict, identity, warmth, support, rewards, and risk) and transfer of training.

\subsection{Scope of the Research}

The following points clarify the scope of the research:

1. The current research explores the impact of organizational climate on transfer of training in case of only one Qatari public corporation. Based on that, the study explores the issue of organizational climate and transfer of training in the case of a single organization, no other organizations were included.

2. Data was collected on February 2021. The results of the study are based on the results of data collected from a relatively small random sample of employees and did not include all employees who work for the selected corporation.

\section{Literature Review}

\subsection{What is Transfer of Training?}

Organizations make investment in training, and they want to make sure that training positively influences performance (Pukkeeree,2017). Therefore, transfer of training into the workplace is mainly about making efforts to make sure that employees transfer what they learned from training into the real-world workplace. Goldstein \& Ford (2012) summarized the idea of transfer of training by saying that training typically involves learning new knowledge, skills, attitudes or other characteristics in one environment (the training situation) that can be applied or used in another environment (the performance situation). 
By this way, the core ideas behind transfer of training is to apply knowledge and skills gained from training in the workplace. Presumably, what was learned in training should be applied to performance on the job.

The more the employees apply what they learn from training in the performance situation, the more the successful of training and investment in training (Schiattone,2017). For Prasad et al., (2018), training transfer is a cognitive function, which involves reasoning, memory, attention and attainment of information such as knowledge and skills. More specifically, the maximization of training transfer has been shown to lead to greater knowledge retention of safety skills and knowledge in construction workers. Perkins \& Salomon (2012) argue that transfer of training into the workplace is mainly about the applying of what trainee gain from training in terms of knowledge, skills, and attitudes, into the workplace to enhance organizational performance. As organizations invest in training, they look for high returns on their investments. High level of transfer of training is an indicator of the returns of investment on training. However, transfer of training into the workplace does not take place completely all the time. For Rouiller (2018) there are three types of transfer of training: positive, negative, and neutral. The positive transfer of training takes place when employees transfer training into work place. If the training results in negative effects on performance, this is an indicator of negative transfer of training. No transfer happens if learning in the training situation has no effect on the job performance.

\subsection{Factors that Influence Transfer of Training}

Many researchers think about how to maximize transfer of training. For example, Kauffeld (2017) found that organizations aiming at improving training transfer should focus on enhancing the participants' motivation and volition to transfer. Both trainers and supervisors seem to promote transfer of training by influencing a trainee's motivation to transfer and volition to transfer. Scholars investigated the association between transfer of training and many personal and organizational factors. For example, some researchers argue that trainees themselves are the key factor of the success or failure of transfer of training. This is because there is association between trainee motivation, skills, readiness, and enthusiasm in one hand, and transfer of training on the other hand. Singh (2017), Wentling (2007), Marguerite (1993), Bereri (2008), and Brinia (2012) concluded that there was high degree of association between trainee motivation, attitudes, 
commitment, characteristics, self-efficacy, cognitive ability, and personal factors (employee educational qualifications and work experience) on one hand, and transfer of training on the other hand. Some researchers argue that transfer of training is influenced mainly by training process.

For example, Hardy (2017), Cheng (2001), Brinia (2012), Holton (1996), and Bates (1997) argue that there is association between training design, training needs analysis, training tools and techniques, and trainer qualifications, on one hand, and the transfer of training on the other hand. For other researchers, the key factors that influence transfer of training are organizational factors such as culture, structure, climate, work relationships, and support. For example, Kodwani (2017), Abujazar (2014), MarlarMaung \& Chemsripong (2014), and Kia (2013) found that supervisor support and co-workers support play critical role in enhancing transfer of training into the workplace. Park (2018) argue that organizational support and motivation are key factors influence transfer of training.

For Kodwani (2017) and Abujazar (2014), there are many factors influence transfer of training. These factors could be grouped based on the stages of training: before the training, during the training, and after training. For example, before training, factors related to training needs analysis, planning of training activities, training objectives, and trainee-supervisor relationships. By this way, before training take pace, it is important to clearly make analysis for training needs to identify gaps in performance and how to bridge them through training. If the wrong trainee selected for the wrong training course, this negatively influences transfer of training. During training, it is important to make continuous follow up, build supportive relationship between trainers and trainees, and use participative training methods and techniques. Trainer can invite former trainees to attend the class to share their experience and successes with the transfer and implementing the training strategies (Abujazar, 2014). After training, it is important to ease the implementation of what employees learned, and it is important to provide trainees with support to apply what they have learned. Adding to that, trainees should be asked what they will apply and how they will apply what they learned from training. It is suitable to provide technical assistance for trainees and their supervisors can be built into any training system to provide structured follow-up on course deliveries (Abujazar, 2014). 
Grossman (2011) argue that factors that influence transfer of training are too many, still they could be grouped as:

(1) Trainee related factors (such as their motivation, self-efficacy, training needs, and their work experience and qualifications),

(2) Training design related factors (such as training techniques and methods, trainers' qualifications, training environment, and behavioral modeling),

(3) Work environment related factors (mainly supervisor and trainee relationships, organizational climate, and support).

Overall, many factors may enhance or hinder the transfer of training into the workplace. These factors are related to trainees, training design, work climate and support, and job of the trainee. By this way, there is no only one factor, but there are many factors influence transfer of training. These factors may take place before, during, or after training. The impacts of such factors are not at the same level for all trainees and organizations. In simple words, factors related to trainees, organization, and training should be considered.

\subsection{What is Organizational Climate?}

For organizational climate, there are different perspectives regarding what does organizational climate mean. From the perspective of Vijayalakshmi (2017) organizational climate is the set of characteristics that describe an organization that distinguishes one organization from other organizations and are relatively enduring over time and influence the behavior of the people. For Muchinsky (1976) organizational climate is mainly the perceptions of the work environments by employees, which may differ according to organizations. For Schneider (1985) organizational climate is the shared perceptions of employees concerning practices, procedures, and behaviors that are rewarded and supported in the workplace. Majdalani (2017) and Rafferty (2003) described organizational climate as the internal environment quality experienced by the employees. This means that organizational climate is mainly about employee perceptions of work relations, practices, procedures, behaviors, and internal environment. By this way, organizational climate is important as it influences performance. 
For example, Ochieng (2017), Gیksu (2011), Palanski \&Simons (2012), and Kozlowski \& Hults (1987) concluded that organizational climate influences marketing performance, employee's attitude towards the organization, job satisfaction, new product development, and employee acceptance of technology. Unido (2006) concluded that internal business environment - enabling employee autonomy, (giving a degree of freedom to employees in the workplace so that informal learning may occur), supportive management, and an organizational structure that can maximize informal learning opportunities. Sharif (2017) and Berg (2008) concluded that relationship with colleagues, work environment, and monetary rewards are among the key factors that influence learning at the workplace. Macneil (2001) concluded that supervisors who are effective facilitators will utilize their own learning and interpersonal skills to encourage learning opportunities through knowledge- sharing in their work teams, thus improving the team's performance. For Taghipouryan (2017), in the world today, there is a need for innovation in the work process, and consequently, for attention to the drivers of the innovation at the organization in order to gain more competitive advantages. Therefore, organizations need innovative organizational climate to cope with continuous change and challenges of globalization.

\subsection{Dimensions of Organizational Climate}

As there is no one universal definition for organizational climate, researchers come with different list of dimensions of organizational climate. For example, Kee (2018) and Davidson (2001) identified dimensions of organizational climate as:

(1) Leader facilitation and support: This dimension related to the leadership behaviors and style. This dimension is crucial as leadership influences employee behaviors and attitudes in direct and indirect manners. .

(2) Professional and organizational esprit: This dimension identifies the organization identity and how it presents itself in terms of its core values.

(3) Conflict and ambiguity: This dimension related to the clarity of rules and the methods of managing conflicts. It is also related to the degree of cooperation between departments and employees.

(4) Regulations: This dimension related to not only the availability of written rules, but their applications in effective manner. 
(5) Workgroup cooperation and friendliness: This dimension related to friendship relationships. It is also about how employees cooperate with each other and with their supervisors.

Castro \& Martins (2010) identified a dozen of dimensions, as in figure (3). These dimensions include trust relationships between employees and managers, availability of training and development opportunities, employee job satisfaction, leadership style and behaviors, employee work-life balance and wellness, type and methods of communications, strategies of managing performance, reward management, team working and team spirit, work environment, and organization identity and image.

Although there are many approaches to identify the dimensions of organizational climate, still, the dimensions listed by Litwin \& Stringer (1968) are still the most accepted dimensions (Yang,2017). For Ahmad (2018), Litwin \& Stringer dimensions of organizational climate are the most comprehensive and reliable dimensions. Litwin \& Stringer (1968) identified different dimensions of organizational climate. The main dimensions are:

(1) Structure: this dimension is mainly about clarity of roles, authorities, policies, and hierarchy of relationships.

(2) Responsibility: the feeling of being your own supervisor; not having to double check all your decisions; when you have a job to do, knowing that it is your job.

(3) Identity: The feeling that you belong to a company and you are a valuable member of a working team; the importance placed on this kind of spirit).

(4) Reward: The feeling of being rewarded for a job well done; emphasizing positive rewards rather than punishments; the perceived fairness of the pay and promotion policies.

(5) Warmth: The feeling of general good fellowship that prevails in the work group atmosphere; the emphasis on being well liked; the prevalence of friendly and informal social groups.

(6) Support: The perceived helpfulness of the managers and other employees in the group; emphasis on mutual support from above and below. 
(7) Standards: The perceived importance of implicit and explicit goals and performance standards; the emphasis on doing a good job; the challenge represented in personal and group goals.

(8) Risk: this dimension is about willingness to make risky decisions and be innovative.

(9) Conflict: this dimension is about how conflicts between employees and departments are managed and solved.

\subsection{Organizational Climate and Transfer of Training}

Recognizing the importance of organizational climate, many studies investigated the association between organizational climate and transfer of training. For example, Kodwani (2017) and Brinia (2012) found that working climate is among the factors that influence transfer of training. In particular, the transfer climate has been identified as critical to achieving transfer of training in organizations.

Thus, an organization whose climate is favorable for transfer to take place is considered as "supportive", while those whose climate inhibits transfer are regarded as "unsupportive" (Burke \& Baldwin, 1999). Awortwi (2013) concluded that organizational climate factors (management support, peer support, budget availability, motivational level, opportunity to perform, training design, and self-efficacy/ability) are positively related to transfer of training. Dochy (2017) concluded that dimensions of organizational climate, mainly supervisor support and participation, are key factors in transfer of training. It was found that, particularly, involvement in training selection, coaching learning and transfer, and participation in training characterize the role of the supervisor in transfer of training.

Khan (2015) argue that organization climate is a key factor related to work environment, and this factor with other work environment related factors play critical role in transfer of training into the workplace. The main dimensions of the organizational climate that influence transfer of training related to work autonomy, providing continuous feedback, task identity and task significance. Khan (2015) argue that, autonomy can be said to be the critical post-training condition, as trainees feel free to outperform newly learned behavior, thereby making it an integral part of learning and training motivation. This means that although dimensions of the organizational climate that influence transfer of training are many, still, autonomy dimension is the most important one. 
By this way, organizations need to provide employees suitable degree of autonomy to carry their duties and to be innovative in their jobs. This requires participative leadership and team working. It is also requiring low degree of formality and high degree of trust.

Santos (2017) and Rouiller \& Goldstein (1993) argue that the positive or negative transfer of training depends on the organizational climate. At the same time, the nature of the organizational climate may enhance or hinder transfer of training. Based on that, organizational transfer climate is a tool that should be investigated as a potential facilitator for enhancing positive transfer of training into the work environment. Organizations need to take actions to build supportive and positive organizational climate in order to maximize the transfer of training. Organizations should take actions to clarify their objectives, identify roles and duties, encourage team working, ease informal communications, support team working, and reward efforts and innovative ideas. By this way, they prepare the suitable environment that maximize the impacts of training on performance.

Abdullahi (2017) conducted a study in Nigeria to identify factors of organizational climate that contribute the most in affecting the training transfer. He focused on three dimensions of organizational climate: vision, support and participative safety. It was found that although the three dimensions of the organizational climate influence transfer of training, still, support was the most important dimension of organizational climate that influence positive transfer of training. Based on that, in order to ease the transfer of training, employees need the support of their supervisors and coworkers. This is because such support encourages employees to transfer training and apply what they learned in the workplace.

Martin (2010) studied the impact of workplace climate and peer support on transfer of training. He concluded that work climate influences transfer of training in direct and indirect manners. Still, he assured that the influence of peer support work side by side with the influence of the organizational climate. I other words, the organizational climate is not the only factor that influence the transfer of training, this influence takes places side by side with other factors. Still, peer support is a key dimension of organizational climate. The idea of Martin (2010) is that organizations should not focus only on supervisor support, but they also need to consider the support of co-workers. 
Hatala (2007) focused on the use of social network analysis (SNA) to build supportive organizational climate that ease transfer of training into the workplace. He argued that SNA serves as a tool for analyzing a participant's organizational network relationships prior to training to help the facilitator, trainee, and supervisor gain an accurate picture of the transfer climate. The core ideas of Hatala (2007) are related to how to utilize social networks to build better organizational climate that eases transfer of training into the workplace.

Sankey \& Machin (2010) argue that intrinsic benefits play critical role side by side with organizational climate in affecting transfer of training into the workplace. They argue that organizations should focus on strategies that generate more autonomous motivation to attend training among employees. These strategies should include promoting a positive transfer climate using positive reinforcement of the intrinsic benefits of training. By this way, Sankey \& Machin (2010) focused on the role of intrinsic benefits of training rather than organizational climate as the key driver of transfer of training.

B"uker (2016) review the literature related to transfer of training and focus on the determinants of the transfer of training. He found that factors related to work environment, mainly organizational climate, play a critical role in influencing transfer of training. He found that the literature presented the impacts of some dimensions of organizational climate on transfer of tanning. The key dimensions were social support through superiors and colleagues, positive or negative consequences of non-application, social climate within the field of function, organizational structure, and incentive schemes.

Wen (2014) carried a study in Taiwan to investigate the relationship between work climate and transfer of training. It was found that organizational transfer climate was predictor of the positive to both motivations to learn and motivation to transfer. Both motivation to learn and motivation to transfer predict training transfer and played mediator roles of transfer climate to training transfer. This means that the relationship between organizational climate and transfer of training goes through some other variables, such as motivation to learn and motivation to transfer. This also means that organizational climate is not the only factor that influence transfer of training. There are many other factors. 
By this way, although organizations may build supportive organizational climate, still, they may suffer from low degree of transfer of training into the workplace. In this case, it is important not only to build supportive climate, but also to empower and energize employees.

Foxon (1993) considered organizational climate factors as key factors that influence transfer of training. This is because the negative effect of an unsupportive organizational climate on the transfer process accounts for $42 \%$ of the identified inhibiting factors. In other words, lack of supportive organizational climate is a key factor that influence negatively the transfer of training. The failure of supervisors (and, to a lesser degree, the co-workers) to encourage and reinforce application of the training on-the-job is the most commonly cited factor inhibiting transfer (Foxon, 1993). This assures that although transfer of training into the workplace is influenced by many factors, still, the influence of supportive organizational climate is obvious. Nazir (2017) found that transfer climate factors do affect training transfer both directly as well as indirectly via learning motivation.

\section{Research Methodology}

\subsection{Method}

The current research utilized the survey research method. This method is very popular in managerial studies and has been widely used in studies exploring the relationship between organizational climate and training transfer. It was also decided to use an online survey, because it is easy to collect data within a short time and to do so at low cost. An online survey is cheaper than face-to-face, more accurate, quicker to analyse, easier to use for participants, easier to use for researchers, more honest, more selective, and more flexible (Gonsalez, 2012).

\subsection{Research Instrument}

To develop a survey with high degree of validity and reliability, and make sure that the questions in the survey help to answer the research questions and test the research hypothesis, intensive review was made for the literature related to the relationship and impact of organizational climate on transfer of training into the workplace. For employee perceptions of the organizational climate, the survey questionnaire of Litwin \& Stringer (1968) was used. This survey was used on most previous studies and it has high degree of validity and reliability. 
Besides, it is one of the widely used instruments to measure organizational climate in the workplace, which has been used frequently in business organizations (Toulson \& Smith, 1994). The organizational climate survey includes (27) statements related to nine dimensions of organizational climate. For employee perceptions of transfer of training, survey of Brinia (2012) was used. This is because it is with high degree of validity and reliability. The survey included (8) statements related to ability and willingness to transfer training to the workplace.

A 5-point scale is used as follows: $5=$ strongly agree, $4=$ agree, $3=$ somewhat agree, $2=$ disagree, and 1 = strongly disagree. Different actions were taken to ensure reliability and validity of the survey. A pilot study of 20 employees was carried to test the usability and simplicity of the survey. SPSS was used to measure the survey reliability, using the Cronbach's alpha technique. The Cronbach's alpha value was (0.91).

\subsection{Research Sample}

The population of the study includes all employees who work for the selected public corporation. As the total number of employees was (200), it was decided to include all employees in the study. The survey questionnaire was distributed to all employees by using their emails. After three weeks, it was found that the returned surveys were 152 surveys. This means that the response rate was $76 \%$. The survey questionnaire included three questions related to gender, educational qualifications, and work experience. Employees were asked about how long they have been working for the corporation, results of data analysis showed that about half of the employees (51\%) have been working for about 5-10 years. $29 \%$ were with relatively short experience as they have been working for less than $5 \mathrm{v}$ years. $20 \%$ have been working for more than 10 years. This indicates that employees are with different lengths of work experience. 


\section{Figure 1: Work experience of the employees}

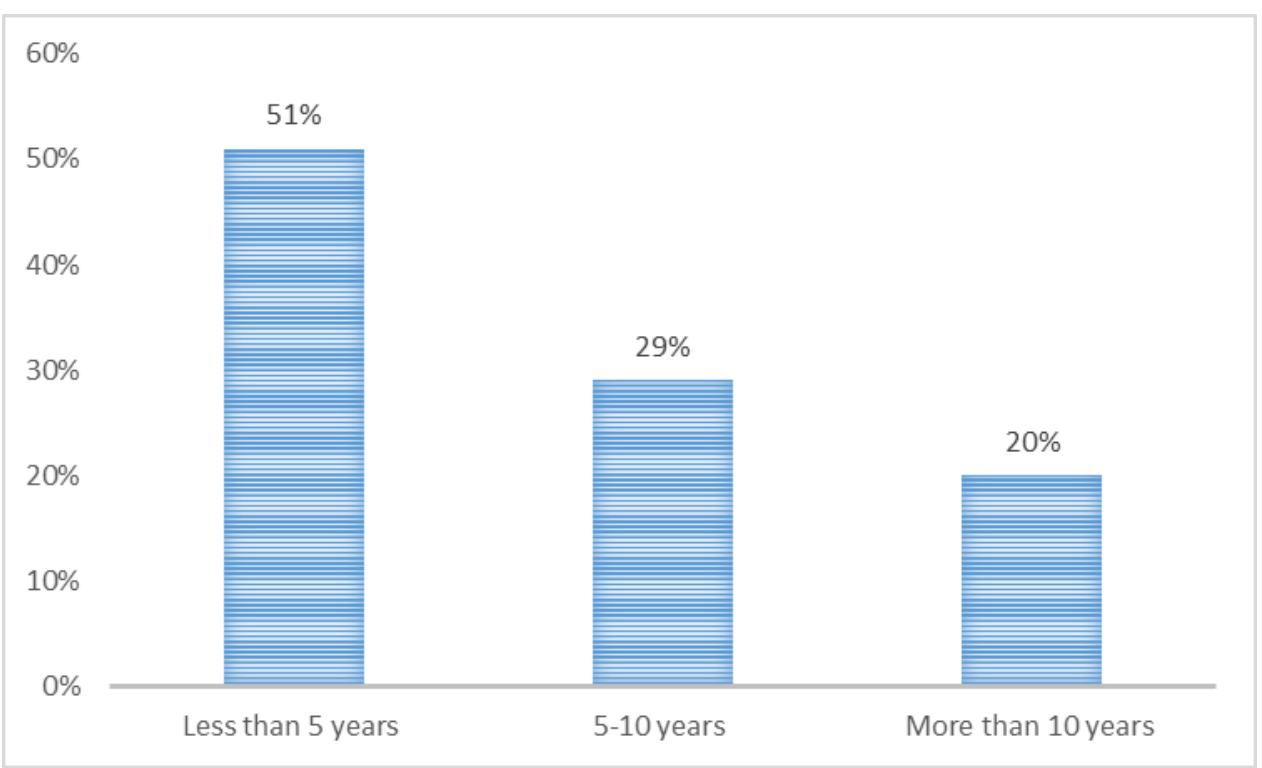

When employees were asked about their educational level (qualifications), it was found that about two-thirds (64\%) were with university degree (bachelor's degree). $15 \%$ of them have Masters/PhD degree. $13 \%$ with secondary certificate, and only $1 \%$ less than secondary. This indicates that employees are relatively well educated.

Figure 2: Educational level (qualifications) of the employees

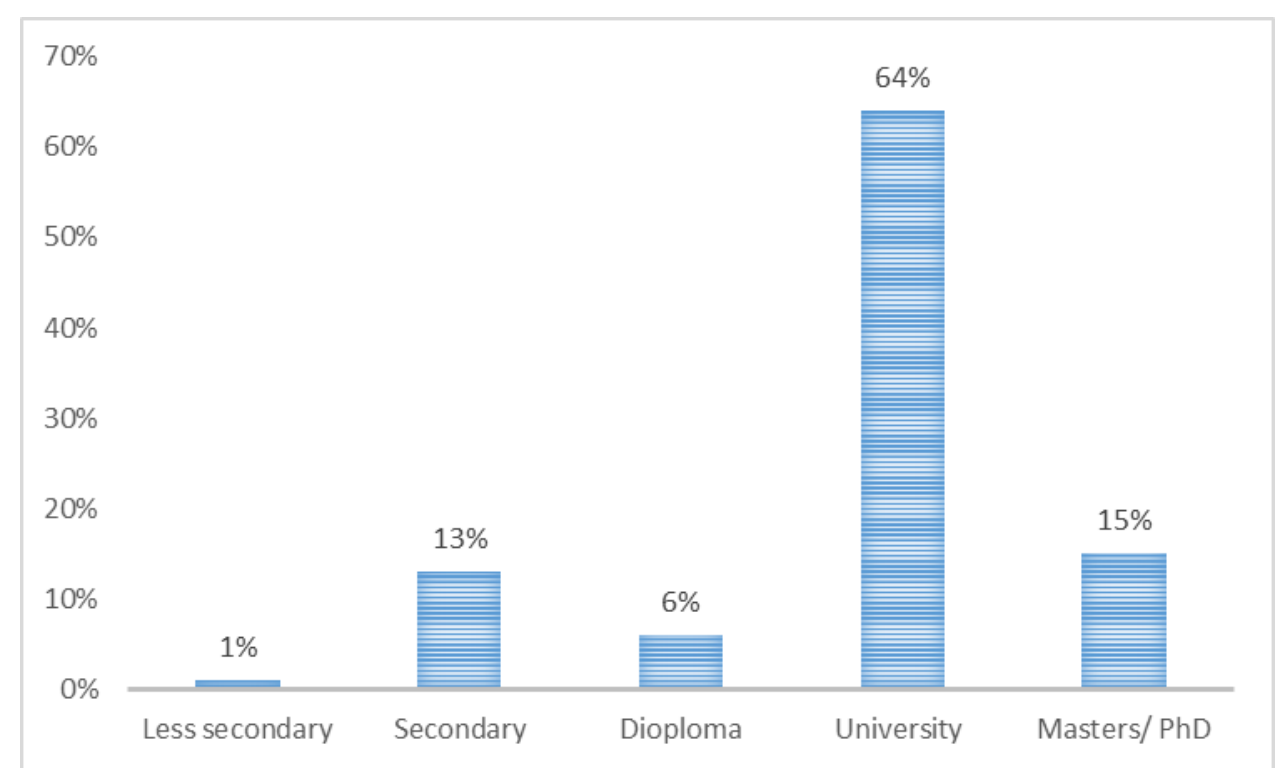

Regarding gender of the employees, results of data analysis showed that $45 \%$ of them were male, and $55 \%$ were female. By this way, the sample included both male and female employees. 
Figure 3: Gender of the employees

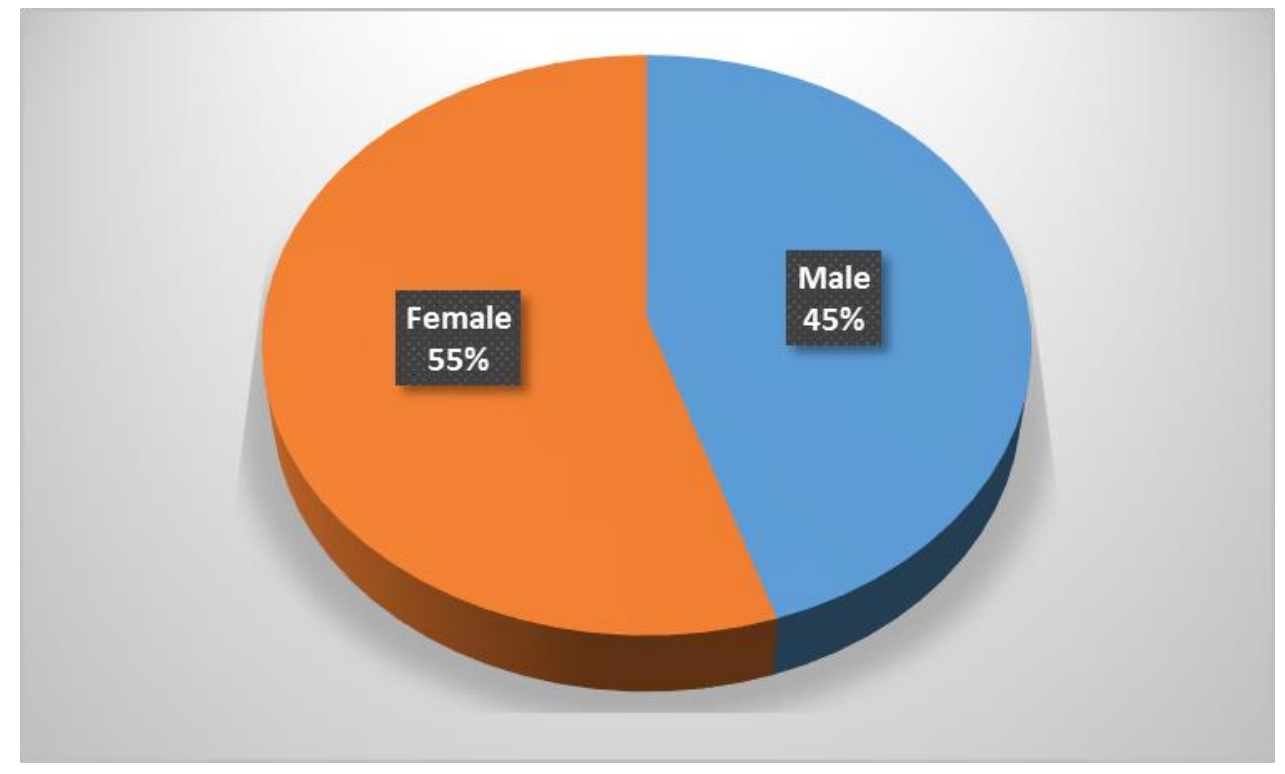

\section{Data Analysis and Findings}

\subsection{Transfer of Training into the Work place}

Results of data analysis showed that there is positive transfer of training into the workplace. The overall mean for transfer of training into the workplace was 4.00 out of 5.00. In other words, employees believe that training influences their performance and behavior. Besides, employees transfer what they learned in training into their workplace. This indicates that employees somewhat agree that they could easily apply what they learned from training into workplace. Table 1: Transfer of training into the work place at the selected public corporation

\begin{tabular}{|l|l|l|}
\hline \multicolumn{1}{|c|}{ Statement } & $\begin{array}{c}\text { Mean } \\
\text { (Average) }\end{array}$ & $\begin{array}{l}\text { Standard } \\
\text { Deviation }\end{array}$ \\
\hline $\begin{array}{l}\text { 1. I can easily apply what I learned from training into } \\
\text { workplace. }\end{array}$ & 3.89 & 0.87 \\
\hline $\begin{array}{l}\text { 2. I am encouraged to apply knowledge, skills, behaviors, } \\
\text { and attitudes gained in training to the real job context. }\end{array}$ & 4.22 & 0.92 \\
\hline 3. Training has clear impacts on my performance. & 4.09 & 0.88 \\
\hline
\end{tabular}




\begin{tabular}{|l|l|l|}
\hline $\begin{array}{l}\text { 4. Training has clear impacts on my behavior and work } \\
\text { relationships. }\end{array}$ & 4.05 & 0.97 \\
\hline $\begin{array}{l}\text { 5. Because of training, I become more effective in doing my } \\
\text { duties. }\end{array}$ & 3.86 & 0.95 \\
\hline $\begin{array}{l}\text { 6. My knowledge about issues related to my job have } \\
\text { increased because of training. }\end{array}$ & 4.03 & 0.93 \\
\hline $\begin{array}{l}\text { 7. My performance after training becomes better than it was } \\
\text { before training. }\end{array}$ & 4.01 & 0.88 \\
\hline $\begin{array}{l}\text { 8. I find that what I learned from training could be applied } \\
\text { into workplace. }\end{array}$ & 3.88 & 0.98 \\
\hline Overall transfer of training into the workplace & $\mathbf{4 . 0 0}$ & $\mathbf{0 . 9 2}$ \\
\hline
\end{tabular}

This is an indicator of positive transfer of training into the workplace. It also indicates that the gap between the training and workplace is not too much.

This is because employees believe that they are encouraged to apply knowledge, skills, behaviors, and attitudes gained in training to the real job context. Employees agree that training has clear impacts on their performance, behaviors, and work relationships. Besides, employees believe that they become more effective in doing their duties and more aware of about issues related to their jobs, because of training. Overall, regarding transfer of training into the workplace, employees agree that they transfer training into the workplace. By this way, training positively influences employee performance, knowledge, work relationships, and daily duties.

\subsection{Employee Perceptions of the Organizational Climate}

Results of data analysis revealed that employees perceive the overall organizational climate positively. The average of all statements related to organizational climate was 3.51 out of 5.00, and it gives indicator of positive attitudes and perceptions of organizational climate.

Table 2: Employee perceptions of the overall organizational climate

\begin{tabular}{|l|l|l|}
\hline Dimension & Mean (Average) & Standard Deviation \\
\hline Structure & 3.13 & 0.99 \\
\hline Responsibility & 3.26 & 0.98 \\
\hline
\end{tabular}




\begin{tabular}{|l|l|l|}
\hline Reward & 2.78 & 0.98 \\
\hline Risk & 3.17 & 0.95 \\
\hline Warmth & 4.04 & 0.92 \\
\hline Support & 4.07 & 0.95 \\
\hline Standards & 3.58 & 0.96 \\
\hline Conflict & 3.31 & 1.05 \\
\hline Identity & 4.30 & 0.96 \\
\hline Overall organizational climate & $\mathbf{3 . 5 1}$ & $\mathbf{0 . 9 7}$ \\
\hline
\end{tabular}

Regarding the dimensions of organizational climate, the averages of (8) dimensions were more than 3.00, but the average of only on dimension "reward" was less than 3.00.

This indicates that employees perceive all dimensions of organizational climate positively, except the dimension of reward. The average of the dimension of "Identity" was the highest 4.30, then the average of the dimension of "Support" 4.07, and then "Warmth" 4.04.

\subsection{The Relationship between Organizational Climate and Transfer of Training}

Results of data analysis showed that there is strong and positive correlation between employee perceptions of the organizational climate and transfer of training into the workplace. The value of Pearson Correlation was significant at 0.000. This means that as employees perceive the organizational climate in positive way, they tend to transfer training into the workplace. It also means that one of the key factors that justify positive transfer of training into the workplace is the positive perceptions of the organizational climate. This assures that while organizations seek to maximize the contributions of training and its influence on performance, it is important to build positive and supportive organizational climate. Results also revealed that there are strong and positive relationships between employee perceptions of eight dimensions of organizational climate and transfer of training into the workplace. It was found that there were positive and strong relationships between:

1. Employee perceptions of support in the workplace and their perceptions of training transfer.

2. Employee perceptions of risk in the workplace and their perceptions of training transfer. 
3. Employee perceptions of responsibility in the workplace and their perceptions of training transfer.

4. Employee perceptions of identity in the workplace and their perceptions of training transfer.

5. Employee perceptions of warmth in the workplace and their perceptions of training transfer.

6. Employee perceptions of structure in the workplace and their perceptions of training transfer.

7. Employee perceptions of conflict in the workplace and their perceptions of training transfer.

Table 3: The relationship between organizational climate and transfer of training

\begin{tabular}{|l|l|l|}
\hline Dependent variable: transfer of training into the workplace & Sign. \\
\hline Independent variables: & $\begin{array}{l}\text { Pearson } \\
\text { Correlation }\end{array}$ & $\mathbf{0 . 0 0 1}$ \\
\hline Employee perceptions of support in the workplace & 0.617 & $0.000^{* *}$ \\
\hline Employee perceptions of rewards & -0.098 & 0.259 \\
\hline Employee perceptions of risk in the workplace & 0.287 & $0.000^{* *}$ \\
\hline Employee perceptions of responsibility & 0.345 & $0.000^{* *}$ \\
\hline Employee perceptions of identity & 0.631 & $0.000^{* *}$ \\
\hline Employee perceptions of warmth in the workplace & 0.628 & $0.000^{* *}$ \\
\hline Employee perceptions of structure & 0.256 & $0.000^{* *}$ \\
\hline Employee perceptions of conflict in the workplace & 0.425 & $0.000^{* *}$ \\
\hline Employee perceptions of standards & 0.475 & $0.000^{* *}$ \\
\hline Employee perceptions of the organizational & $\mathbf{0 . 4 6 5}$ & $\mathbf{0 . 0 0 0 * *}$ \\
climate & & \\
\hline
\end{tabular}

Still, the relationship employee perceptions of rewards and their perceptions of training transfer was weak and not significant. This indicates that as employees perceive all dimensions of organizational climate positively, 
Except the dimension of reward, there was strong and positive relationships between employee perceptions of eight dimensions of organizational climate and transfer of training into the workplace. The relationship employee perceptions of rewards and their perceptions of training transfer was weak and not significant.

\subsection{Discussion of the Findings}

Results showed that there was positive transfer of training into the workplace. This result does not go with Baldwin \& Ford (1997) who noted only 10 percent of training outcomes are transferred back to the job. This result also does not go with Rackman \& Ruff (1991) who concluded that within employees might remember only 13 percent, and they may apply less than that. There are many reasons that could help to explain such positive transfer of training in the workplace. On one hand, this could be attributed to high degree of harmony between what trainees learned and the real workplace situation (Jelsma et al, 1990). In other words, there is low level of gaps between training and workplace. This is mainly because training at the selected public corporation is delivered based on analysis of employee training needs. Side by side, training courses are designed and tailored to meet specific training needs and objectives. By this way, it is important to make analysis for training needs to identify gaps in performance and how to bridge them through training. If the wrong trainee selected for the wrong training course, this negatively influences transfer of training (Abujazar, 2014).

This assures that there is association between training design and transfer of training (Cheng, 2001, Brinia 2012, Holton, 1996, Bates, 1997). On the other hand, this positive transfer of training could be attributed to trainees themselves in terms of their motivation and readiness (Brinia, 2012). By this way, employees in different organizations perceive transfer of training into the workplace differently. Therefore, employees in one organization may perceive transfer of training positively, while employees of other organization perceive it negatively. This is mainly because organizations are not identical in their cultures, structures, strategies, and work relationships. This assures organizational factors such as culture, structure, climate, work relationships, and support play critical role in enhancing transfer of training into the workplace (Abujazar, 2014, MarlarMaung \& Chemsripong, 2014, Kia, 2013). 
The current study also revealed that there is positive relationship between organizational climate and transfer of training. The results of the current study regarding the relationship between organizational climate and transfer of training support the results of studies of Brinia (2012), Burke \& Baldwin (1999) and Awortwi (2013) who concluded that concluded that organizational climate factors (management support, peer support, budget availability, motivational level, opportunity to perform, training design, and self-efficacy/ability) are positively related to transfer of training. This means that an organization whose climate is favorable for transfer to take place is considered as "supportive", while those whose climate inhibits transfer are regarded as "unsupportive". The results of the current study also go with the results of the studies of Khan (2015) Rouiller \& Goldstein (1993), and Abdullahi (2017) who concluded that organization climate is plays critical role in transfer of training into the workplace. This assures that the positive or negative transfer of training depends on the organizational climate. By this way, the nature of the organizational climate may enhance or hinder transfer of training. Based on that organizations need to take actions to build supportive and positive organizational climate in order to maximize the transfer of training. Organizations should take actions to clarify their objectives, identify roles and duties, encourage team working, ease informal communications, support team working, and reward efforts and innovative ideas. By this way, they prepare the suitable environment that maximize the impacts of training on performance.

\section{Findings, Recommendations, and Conclusion}

\subsection{Key Findings}

Results of data analysis revealed that:

1. Transfer of training into the workplace: It was found that there are positive attitudes towards transfer of training. In other words, employees believe that training influences their performance and behavior. Besides, employees transfer what they learned in training into their workplace. Employees agree that they transfer training into the workplace. By this way, training positively influences employee performance, knowledge, work relationships, and daily duties. This indicates that in case of the selected public corporation, training influences performance, and training effects are transferred into the workplace. 
2. Employee perceptions of the organizational climate: Results of data analysis revealed that employees perceive the overall organizational climate positively. This gives indicator of positive attitudes and perceptions of organizational climate.

3. Employee perceptions of the dimensions of the organizational climate: Results of data analysis revealed that the averages of (8) dimensions were more than 3.00, but the average of only on dimension "reward" was less than 3.00. This indicates that employees perceive all dimensions of organizational climate positively, except the dimension of reward. The average of the dimension of "Identity" was the highest 4.30 , then the average of the dimension of "Support" 4.07, and then "Warmth" 4.04.

4. The relationship between organizational climate and transfer of training: Results of data analysis revealed that there is strong and positive correlation between employee perceptions of the organizational climate and transfer of training into the workplace. This means that as employees perceive the organizational climate in positive way, they tend to transfer training into the workplace.

5. The relationship between the dimensions of organizational climate and transfer of training: Results of data analysis revealed that there are strong and positive relationships between employee perceptions of eight dimensions of organizational climate and transfer of training into the workplace. It was found that there were positive and strong relationships between employee perceptions of support, responsibility, structure, conflict, identity, warmth, support, and risk on one hand, and their perceptions of training transfer on the other hand. Still, the relationship employee perceptions of rewards and their perceptions of training transfer was weak and not significant. This indicates that as employees perceive all dimensions of organizational climate positively, except the dimension of reward, there was strong and positive relationships between employee perceptions of eight dimensions of organizational climate and transfer of training into the workplace. The relationship employee perceptions of rewards and their perceptions of training transfer was weak and not significant. 


\subsection{Recommendations}

Based on the results of the current study, the management of the public corporation needs to:

1. Build positive and supportive organizational climate to maximize the levels of transfer of training into the workplace. By this way, the impacts of training on performance will increase. This in return influences the performance positively.

2. Review and improve rewards. This is mainly because the relationship employee perceptions of rewards and their perceptions of training transfer was weak and not significant. Employees perceive the dimension of rewards negatively.

3. Raise awareness among employees regarding the importance of transfer of training and ease the transfer of training into the workplace. For example, it is important to encourage employees to apply knowledge, skills, behaviors, and attitudes gained in training to the real job context.

4. Improve the organizational structure and policies. This is because employees believe that not only jobs need to be structured in better way, but also they believe that policies and organization structure should be explained in more clear way. If structure and policies are improved, this may enhance the transfer of training into the workplace.

5. Encourage employees to carry responsibility and be risk takers. This is because employees tend to avoid and escape from responsibility. It is also important to encourage risk taking to encourage employees to come up with innovative ideas.

\subsection{Future Studies}

Although the current study found that there is strong relationship between organizational climate and transfer of training, but there are other factors that may influence such relationship It is suggested to carry future studies about the impact of leadership style on transfer of training. It is also recommended to carry future study about HRM practices and transfer of training. The relationship between organizational structure and culture on one hand and transfer of training on the other hand may take place in the future. 


\subsection{Conclusion}

The results of the current study assure the impact of organizational climate on transfer of training into the workplace. This means that as organizations seek to maximize transfer of training into the workplace, they need to build supportive and warmth organizational climate. It was concluded that organization climate plays critical role in transfer of training into the workplace. This assures that the positive or negative transfer of training depends on the organizational climate. By this way, the nature of the organizational climate may enhance or hinder transfer of training. As there are many dimensions related to organizational climate, the impact of such dimensions at transfer of training is not at the same level. The impacts of some dimensions are much bigger than the impacts of other dimensions. In the current study, the effects of the dimensions of identity, warmth, and support were higher than the effects of other dimensions. Based on that, in order to ease the transfer of training, employees need the support of their supervisors and coworkers. This is because such support encourages employees to transfer training and apply what they learned in the workplace.

\section{References}

Abdullahi, A. 2017. Relationship between Organizational Climate and Training Transfer in Small and Medium Enterprises in Nigeria. European Journal of Business and Management. Vol. 9 (2), pp. 111-123.

Abujazar, S. 2014. Factors affecting transfer of training. Master's Thesis. University of South California.

Ahmad, A. 2018. Organizational climate and job satisfaction: do employees' personalities matter? Management Decision, Vol. 56 Issue: 2, pp.421-440.

Awortwi, T. 2013. The Effect of Organizational Climate on Transfer of Training. A Study of Asa Ghana. Master's Thesis. University of Ghana.

Baldwin, T. and Ford, J.1988. Transfer of training: a review and directions for future research. Personnel Psychology. (vol. 41), pp. 63105. 
Banerjee, P., Gupta, R. \& Bates, R. 2017. Influence of Organizational Learning Culture on Knowledge Worker's Motivation to Transfer Training: Testing Moderating Effects of Learning Transfer Climate. Current Psychology. Vol. 1. Pp. 36: 60.

Bates, R. 1997. The impact of training content validity, organizational commitment, learning, performance utility, and transfer climate on transfer of training in an industrial setting. Doctoral dissertation, Louisiana State University.

Berg, S. 2008. Factors that influence informal learning in the workplace", Journal of Workplace Learning, (Vol. 20 Iss. 4), pp.229 - 244

Bhatia, A.2014. Global Training \& Development trends \& Practices: An Overview. International Journal of Emerging Research in Management \&Technology. (Volume-3, Issue-8). 75-96.

Bereri, E. 2008. Trainee perceptions of training transfer: an empirical analysis. Journal of European Industrial Training. (Vol. 33. Issue: (3), pp. 255-270.

Blume, C. 2017. The State of Transfer of Training Research: Moving Toward More ConsumerCentric Inquiry. Human Resource Development Quarterly. Volume 28, Issue 1. Pp. 17-28.

Brinia, V.2012. Evaluation of factors affecting training transfer on safety in the workplace: a case study in a big factory in Greece. Industrial and Commercial Training. Vol. 44. Issue: (4) pp.223 $-231$.

Broad, M.2008. Beyond transfer of training: Engaging systems to improve performance. San Francisco, CA: John Wiley \& Sons.

B“uker, R. 2016. Determinants of transfer of training: A comprehensive literature review. International Journal for Research in Vocational Education and Training. Vol. 3, pp. 127-165

Burke, L. \& Baldwin, T. 1999. Workforce training transfer: A study of the effect of relapse prevention training and transfer climate. Human Resource Management. Vol. 38, Iss. pp. 227241

Castro, M., \& Martins, N. 2010. The relationship between organizational climate and employee satisfaction in a South African information and technology organization. SA Journal of Industrial Psychology. Vol. 6(3), pp. 211-223. 
Cheng, W. 2001. A Review of Transfer of Training Studies in the Past Decade. Personnel Review. (Vol. 30). pp. 102-118.

Chiaburu, D. \& Tekleab, G.2005. Individual and contextual influences on multiple dimensions of training effectiveness. Journal of European Industrial Training, (Vol. 29. No. (8) pp.604 - 626

Clark, C. Dobbins, G. \& Ladd, R. 1993. Exploratory field study of training motivation. Group Organization Management. (Vol. 18, No. (3), pp.292-307

Davidson, D. 2001. The Dimensions of Organizational Climate in Four- and Five-Star Australian Hotels. Journal of Hospitality and Tourism Research. Vol. 13 Issue: 1, pp.119-1139.

Dochy, D. 2017. A Supervisors' Perspective on Their Role in Transfer of Training. Human Resource Development Quarterly. Vol. 9, pp. 47- 58.

Ford, J., Smith, E., Weissbein, D., Gully, S. and Salas, E. 1997. Relationships of goal orientation, metacognitive activity, and practice strategies with learning outcomes and transfer. Journal of Applied Psychology, Vol. 8, pp. 218-233.

Foxon, M. 1994. A process approach to the transfer of training. Part 2: Using action planning to facilitate the transfer of training. Australian Journal of Educational Technology. (Vol. 10, No. (1), pp.1-18.

Göksu, N. (2011). The Impact of Organizational Climate on New Product Development Performance: A Case Study on Textile Sector in Turkey. Faculty of Economics and Administrative Sciences Journal, (Vol. No. 1 (1), pp. 57-72.

Goldstein, I. and Ford, J. 2002. Training in organizations. Belmont, CA: Wadsworth.

Graham, M. 2005. How to maximize your investment in IT training", Human Resource Management International Digest, (Vol. 3, No. (2), pp.3 - 4

Greg, G. \& Diane, W. 2006. Training Evaluation: Knowing More Than Is Practiced. Advances in Developing Human Resources, (Vol. 7. No. (1), 16-21 
Gupta, G. 2016. Human resource management practices and organizational effectiveness: internal fit matters. Journal of Organizational Effectiveness: People and Performance, Vol. 3 Issue: 2, pp.139-16

Hatala, A. 2007. Making Transfer Climate Visible: Utilizing Social Network Analysis to Facilitate the Transfer of Training. Human Resource Development Review Vol. 6, No. 1 pp. 1-31

Ho, K. 2001. A review of transfer of training studies in the past decade. Personnel Review, Vol. 30 Issue: 1, pp.102-118.

Holton, E.1996. Toward construct validation of a transfer climate instrument. Human Resource Development Quarterly, (Vol. 8, No. (2), pp.95-113.

Hunter, M. 1971. Teach for Transfer, A Programmed Book. El Segundo, CA: TIP Publication.

Jelsma, O, Van, J. \& Bijlstra, J. 1990. The ADAPT design model: towards instructional control of transfer. Instructional Science, (Vol. 19). pp. 89-120

Kauffeld, K. 2017. Volition to transfer: mastering obstacles in training transfer. Personnel Review, Vol. 46 Issue: 4, pp.809-82.

Khan, K. 2015. Transfer of Training: A Reorganized Review on Work Environment and Motivation to Transfer. International Journal of Management, Knowledge and Learning, Vol. 4(2), pp. 197-219

Kia, N. 2013. The relationship between Environmental Characteristics and Training Transfer. International Journal of Business and Social Science. (Vol. 4. No. (12) pp. 196-203.

Kirkpatrick, D.C. (1975). Evaluating Training Programs: The Four Levels. San Francisco: Berrett-Kohler.

Kirwan, C. \& Birchall R.2006. Transfer of learning from management development programmer: testing the Holton model. International Journal of Training and Development. (Vol. 10, no. (4) pp. 252-268. 
Kozlowski, S. \& Hults, B. 1987. An exploration of climates for technical (30) updating and performance. Personnel Psychology, (Vol. 40. No. (3), pp. 539-563.

Litwin, G. \& Stringer, R. 196). Motivation and organizational climate. Boston: Division of Research, Harvard Business School.

Macneil, C. 2001. The supervisor as a facilitator of informal learning in work teams. Journal of Workplace Learning, (Vol. 13, no. 6), pp. $246-253$.

Marguerite, F. 1993. Process approach to the transfer of training: part 1: the impact of motivation and supervisor support on transfer maintenance. Canberra, Australian Capital Territory: AJET Publications.

MarlarMaung, K. \& Chemsripong, S. 2014. Work environment factors influence on transfer of training in Myanmar. South East Asia Journal of Contemporary Business, Economics and Law, (Vol. 4. No. (1) pp. 23-39.

Martin, M. 2010. Workplace Climate and Peer Support as Determinants of Training Transfer. Wiley Inter Science Human Resource Development Quarterly, Vol. 21(1), pp. 87-104.

Michalak, D. 1981. The neglected half of training. Training and Development Journal, Vol. 35, pp.22-28.

Morris, F. 2006. Influence of trainee characteristics, instructional satisfaction, and organizational climate on perceived learning and training transfer. Human Resource Development Quarterly. Volume 17, Issue 1. pp. 85-115

Muchinsky, P. 1976. An assessment of the Litwin and Stringer organization climate questionnaire: An empirical and theoretical extension of the Sims and Lafollete study. Personnel Psychology, (Vol. 29. No. (3), 371-392.

Nazir, Z. 2017. An Empirical Examination of The Effects of Personality Traits And Transfer Climate Factors On Transfer Of Training \& Motivation: A Longitudinal Study. Studies in Business and Economics. no. 12(3), pp. 134-151.

O'Leary, Z. 2004. The essential guide to doing research. London: Sage. 
Prasad R., Feng Y., Hardy M. 2018. Factors Influencing Safety Training Transfer on Construction Sites: A Literature Review. In: Chau K., Chan I., Lu W., Webster C. (eds) Proceedings of the 21st International Symposium on Advancement of Construction Management and Real Estate. Springer, Singapore.

Park, R. 2018. Does supervisor support make a difference in employees' training and job performance? An empirical study of a professional development program. European Journal of Training and Development, Vol. 51, pp. 512-530.

Pfeffer, J., 1994. Competitive Advantage through people. Harvard Business School Press, Boston.

Rackham, N. \& Ruff, R. 1991. Managing Major Sales. New York: Harper Business.

Rafferty, T. 2003. School climate and teacher attitudes toward upward communication in secondary schools. American Secondary Education, (Vol. 31. No. (2), 49-70.

Rouiller, J. 1989. Determinants of the climate for transfer of training. Doctoral dissertation. University of Maryland.

Rouiller, R. \& Goldstein, S. 1993. The relationship between organizational transfer climate and positive transfer of training. Human Resource Development Quarterly. Volume 4, Issue 4, pp. $377-390$

Salas, E. 2012. The Science of Training and Development in Organizations: What Matters in Practice. Psychological Science in the Public Interest. (Vol. 2. No. (13) pp.74.

Sankey, S. \& Machin, A. 2010. The role of climate for transfer of training and intrinsic benefits in explaining employees' motivation to attend voluntary professional development activities. In: 27th International Congress of Applied Psychology, 11-16 Jul 2010, Melbourne, Australia.

Srimannarayana, M. 2017. From reactions to return on investment: a study on training evaluation practices. Indian Journal of Industrial Relations, vol. 53, no. 1, pp. 1-18.

Taghipouryan, T. 2017. The role of the organizational climate in the process innovation at sport organizations (Some evidence from the Sports and Youth Departments of Mazandaran Province). International Journal of Applied Exercise Physiology. Vol. 3 Issue: 2, pp.113-140. 
Toulson, P., \& Smith, M. (1994). The relationship between organizational climate and employee perceptions of personnel management practices. Public Relations Management, 23, 453-468

Vandergoot, S. Sarris A., and Kirby, N. 2018. Factors That Influence the Training Transfer and Maintenance of Conflict Resolution Programs of Healthcare Training and Development Units: A Retrospective Study. In: Leung MT., Tan LM. (eds) Applied Psychology Readings. Springer, Singapore.

Vijayalakshmi, V. 2017. A Study to Assess the Organizational Climate of Selected hospital, Chennai as Perceived by Staff Nurses. International Journal of Current Trend. Vol. 4, pp. 147165.

Wentling, T. 2007. Factors associated with transfer of training in workplace e-learning. Journal of Workplace Learning, (Vol. 19. No. (5), pp.311 - 329.

Yearta, D. 1997. Predicting immediate and longer-term transfer of training. Personnel Review, Vol. 26 Issue: 3, pp.201-213.

Wen, C. 2014. How supportive Transfer Climate Affects Individual's Motivation to Training Transfer. International Journal of Learning \& Development. Vol. 4, No. 1. Pp. 87-102.

Yangjing, K. 2018. Development and validation of a questionnaire to evaluate the factors influencing training transfer among nursing professionals. BMC Health Services Research. Vol. 21, pp. 112-130

\section{Doi: doi.org/10.52133/ijrsp.v2.20.4}

